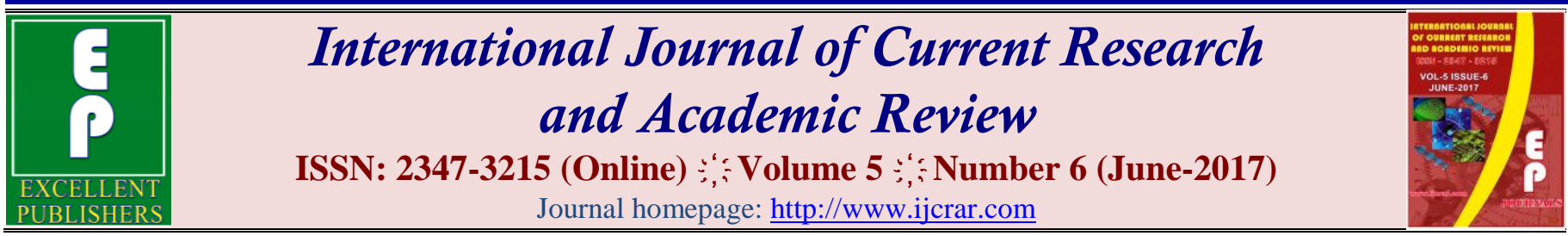

doi: https://doi.org/10.20546/ijcrar.2017.506.014

\title{
Financial Performance Drives Market Performance-An Empirical Investigation by Comparing Two Industries in India
}

\author{
E. Geetha* \\ Department of Commerce, Manipal University, India \\ *Corresponding author:
}

\section{Abstract}

Financial performance is considered as an imperative indicator for market performance. Even now many believe that only financial performance drives the firm's value and helps to increase a large chunk of market share. This study helps us to understand how far financial performance helps the company to impact the market despite the inevitable factors like intellectual capital, structural capital then macro factors like inflation, interest rates, economic\& political factors, etc. This paper focused last 10 years financial performance of 20 companies from two different industries of India, how far their contribution is there towards market performance of those companies based on their financial stability and performance.
\end{abstract}

\section{Article Info}

Accepted: 05 June 2017

Available Online: 20 June 2017

\section{Keywords}

Financial performance, Market performance,

Sub-business.

\section{Introduction}

The analysis of financial statements is an attempt to unravel the way in which the company has been functioning, its direction of growth, extent of growth, ability to stay in the business and also the satisfaction level of the investors. Financial analysis refers to an assessment of the viability, stability, and profitability of a business, sub-business or project. An efficient financial management is necessary for the success of any industry. The IT and automobile industries have a major place in Indian Economy. Their contribution to income generation is very important for the development of the country. The efficiency can be achieved only through proper long term planning to achieve the objectives. In order to understand how efficiently the organization is performing in this field to achieve the goals through economical use of the resources especially in the field of financial resource, it is interdependent on the issues of living standards of the people. With Indian economy moving on to a high growth trajectory facilitated by a consistent and steady growth rate in the recent years, there is a critical need to accelerate investments in the IT and automobile industries. In fact, these two industries have emerged as key drivers for sustaining the robust growth of the economy and the Government has been focusing on development of these industries over the years, especially after the new economic reforms. Although there has been considerable progress in attracting private investments into these industries, their performance is also influenced by both internal and external factors. There is great need to examine the performance of these industries as they attract huge amount of investment and also employ considerable amount of workers. The fluctuations in their growth are capable of influencing the rate of capital formation in the economy and also the level of employment generation. Better financial management is essentially required for optimizing the resources and maximizing productivity and efficiency of the industry. From this view point, the financial and market 
performance of the IT and automobile industries need to be analyzed which is done in this study.

\section{Significance of the problem}

The Indian economy underwent marked structural changes in 1991 with the introduction of liberalization, privatization, and globalization. This opened up the scope and vistas of the industries both in the manufacturing and service sectors, which is especially true in the case of both the IT and automobile industries. These two industries have attracted and also continue to attract huge amount of investment not only from Indian investors but also from investors belonging to other countries. However, the rate of growth of the industries is not quite stable, as it is influenced by the fluctuations in the overall sectors and also the economy. Moreover, as the developed economy is more globalized, changes in the economic activities at the global level directly influence the performance of these industries in India as well. Hence, the performances of the IT and automobile industries have been undergoing different phases in the last 10 years. The level of sales, profit, investment, employment, output and also exports from these two industries have been fluctuating which requires methodical analysis of the same, which is attempted in this study.

\section{Results and Discussion}

This segment analyses the financial performance of the companies which have been selected from the IT and Automobile sectors for this study. As the 20 companies that belong to the two industries differ in many aspects, their financial performance will also differ quite expectedly. Thus, the performance of these sample companies like the current ratio, quick ratio, debt-equity ratio, etc, in the study period is analysed.

It is observed from table 1 that the mean current ratio of all the 20 companies in 2005-06 was 1.450 , which has gone up to 1.560 in 2009-10, but has come down to 1.394 in 2013-14. The minimum ratio indicates that it has gone from a positive score to a negative score in the study period, while the maximum score too has gone down from 7.001 in 2011-12 to 6.365 in 2014-15. These changes have also resulted in rising SD levels, which have gone up from 0.825 in 2005-06 to 4.490 in 2014-15.

The test result indicates that the calculated F-value of 12.045 is statistically significant at 1 per cent level (Table 2 ), and it is greater than the table value of 1.645 (Table
5), which suggests that when all the sample companies taken together too, the variation in the current ratio among them is statistically significant, though the degree of variation has come down, as suggested by the F-value (Table 2).

It is inferred from table 3 that the mean debt-equity ratio of all the companies in 2005-06 stood at 2.826 increased continuously and touched 14.891 in 2014-15, which shows the worsening debt-equity ratio, particularly in the case of IT companies, since as table 3 suggests, the ratio has gone up from 1.052 to 22.626 in the study period among the IT companies, while the same has moved up from 4.600 to 7.157 among the automobile companies, though it stood at 10.844 in 2011-12. Thus, the debt position of the IT companies has worsened much compared to that of the automobile companies. This is also brought out by the fact that the highest maximum ratio among the IT companies stood at 200.98 vis-à-vis that of 42.244 in the case of the automobile companies. Moreover, the SD values have also been quite high in the case of the former than that of the latter. This indicates that as a group, the IT companies have made greater negative impact in the overall performance in the debtequity ratio compared to that of the automobile companies.

It is noted that the variation in the debt-equity ratio among all the companies is also statistically significant at 1 per cent level, since when the companies that belong to the IT and automobile sectors taken together, the degree of variation is marginally levelled out, as suggested by the F-value, though it is still statistically significant.

It is observed from table 5 that the overall mean net profit ratio has increased only marginally from 0.123 to 0.156 in the ten year period and the highest maximum ratio for the entire period being only 0.418 which has been attained in 2012-13, while the least minimum net profit ratio has been -0.004 that has occurred in 2011-12.

As far as the IT sector is concerned, the mean net profit ratio has fluctuated between 0.209 in 2004-05 and 0.254 in 2013-14, which hit the low of 0.143 in 2012-13. Both the highest maximum and the least minimum values have been posted by this sector, which brings out the extent of variation in it. In the case of the automobile sector, the mean ratio has increased only marginally from 0.038 to 0.057 in the ten year period, though it was as high as 0.071 in 2011-12, which suggests that it not even touched 0.100 in any of the years. Thus, the mean net profit ratio 
earned by the automobile sector is far too low compared to that of the IT sector in the study period.

Market performance of the selected companies of Automobile and IT industry

The mean return earned by the two industries differs among them in each of the year and to bring more clarity, the year-wise industry-wise mean adjusted returns are compared and the difference between them is also arrived, which is presented in table 6 .

Comparison of the adjusted mean return posted by the companies under Sensex and Nifty indicates that under Sensex, the companies that belong to the automobile sector has performed better than the companies that belong to the IT sector in six out of ten years, with the exception of 2008-09, 2009-10 and 2012-13, in which years, the companies that belong to the IT sector have performed better than the companies that belong to the automobile sector. However, during 2011-12, there is no difference in the adjusted mean returns posted by the companies that belong to these two sectors. In terms of Nifty, the performance of the automobile companies is better in all but one year, the exception being 2009-10, in which year, both sectors have posted similar returns. Thus, in terms of Nifty, in none of the years, the companies that belong to the IT sector could perform better than the companies that belong to the automobile sector. This underscores the fact that the market performance of the selected automobile companies is better during the period under study compared to that of the selected IT companies.

Table.1 Industry and year-wise mean current ratio, 2005-06 to 2014-15

\begin{tabular}{|l|r|r|r|r|r|l|l|l|r|r|}
\hline & 2006 & 2007 & 2008 & 2009 & 2010 & 2011 & 2012 & 2013 & 2014 & 2015 \\
\hline \multicolumn{10}{|c|}{ All Companies } \\
\hline Mean & 1.450 & 1.264 & 1.305 & 1.201 & 1.111 & 1.560 & 1.506 & 1.477 & 1.349 & 1.394 \\
\hline SD & 0.825 & 0.634 & 0.622 & 0.632 & 1.080 & 1.431 & 1.464 & 1.474 & 1.526 & 4.490 \\
\hline Min & 0.278 & 0.342 & 0.549 & 0.369 & 0.403 & 0.275 & 0.131 & 0.285 & -0.513 & -0.162 \\
\hline Max & 3.903 & 2.594 & 2.558 & 2.529 & 2.717 & 5.855 & 7.001 & 6.782 & 6.865 & 6.355 \\
\hline \multicolumn{10}{|c|}{ Information Technology } \\
\hline Mean & 2.126 & 1.712 & 1.796 & 1.569 & 1.410 & 2.439 & 2.277 & 2.232 & 1.889 & 2.064 \\
\hline SD & 0.930 & 0.652 & 0.444 & 0.697 & 0.691 & 1.469 & 1.854 & 1.734 & 1.988 & 1.947 \\
\hline Min & 0.810 & 0.842 & 1.246 & 0.369 & 0.500 & 1.061 & 0.131 & 0.942 & -0.513 & -0.162 \\
\hline Max & 3.903 & 2.594 & 2.558 & 2.529 & 2.717 & 5.855 & 7.001 & 6.782 & 6.865 & 6.355 \\
\hline \multicolumn{10}{|c|}{ Automobile } \\
\hline Mean & 0.773 & 0.816 & 0.814 & 0.834 & 0.812 & 0.682 & 0.735 & 0.721 & 0.809 & 0.724 \\
\hline SD & 0.284 & 0.281 & 0.241 & 0.303 & 0.414 & 0.328 & 0.364 & 0.341 & 0.638 & 0.543 \\
\hline Min & 0.278 & 0.342 & 0.549 & 0.429 & 0.403 & 0.275 & 0.132 & 0.285 & 0.280 & 0.182 \\
\hline Max & 1.087 & 1.188 & 1.352 & 1.511 & 1.788 & 1.374 & 1.230 & 1.428 & 2.537 & 2.102 \\
\hline
\end{tabular}

Source: Computed.

Table.4.6 Variation in current ratio of all sample companies, 2005-06 to 2014-15

\begin{tabular}{|l|c|c|c|c|c|c|}
\hline \multicolumn{1}{|c|}{ Variation } & $\boldsymbol{S S}$ & $\boldsymbol{d} \boldsymbol{f}$ & $\boldsymbol{M S}$ & $\boldsymbol{F}$ & $\boldsymbol{P}$-value & $\boldsymbol{F}$ crit \\
\hline Between Groups & 147.061 & 19 & 7.740 & $\mathbf{1 2 . 0 4 5}^{* * *}$ & $3.52 \mathrm{E}-23$ & 1.9294 \\
\hline Within Groups & 115.667 & 180 & 0.642 & & & \\
\hline Total & $\mathbf{2 6 2 . 7 2 7}$ & $\mathbf{1 9 9}$ & & & & \\
\hline
\end{tabular}

Note: *** indicates 1 per cent level of significance; Source: Computed. 
Table.1.3 Industry and year-wise mean debt-equity ratio, 2005-06 to 2014-15

\begin{tabular}{|l|c|c|c|c|c|c|c|c|c|c|}
\hline & 2006 & 2007 & 2008 & 2009 & 2010 & 2011 & 2012 & 2013 & 2014 & 2015 \\
\hline \multicolumn{10}{|c|}{ All Companies } \\
\hline Mean & 2.826 & 2.647 & 4.084 & 5.375 & 6.760 & 12.577 & 13.076 & 13.510 & 14.053 & 14.891 \\
\hline SD & 3.651 & 5.448 & 7.034 & 9.199 & 18.310 & 25.413 & 29.913 & 35.012 & 40.805 & 31.059 \\
\hline Min & Nil & Nil & Nil & Nil & Nil & Nil & Nil & Nil & Nil & Nil \\
\hline Max & 9.07 & 16.21 & 26.68 & 28.06 & 38.15 & 99.64 & 122.77 & 148.77 & 173.50 & 200.98 \\
\hline \multicolumn{8}{|c|}{ Information Technology } \\
\hline Mean & 1.052 & 0.592 & 1.508 & 2.753 & 3.331 & 14.377 & 15.308 & 18.327 & 20.449 & 22.626 \\
\hline SD & 2.371 & 1.548 & 4.146 & 5.570 & 6.787 & 30.870 & 38.084 & 46.122 & 54.003 & 62.885 \\
\hline Min & Nil & Nil & Nil & Nil & Nil & Nil & Nil & Nil & Nil & Nil \\
\hline Max & 7.42 & 4.95 & 13.28 & 13.54 & 17.11 & 99.64 & 122.77 & 148.77 & 173.50 & 200.98 \\
\hline \multicolumn{8}{|c|}{ Automobile } \\
\hline Mean & 4.600 & 4.703 & 6.660 & 7.998 & 10.189 & 10.776 & 10.844 & 8.694 & 7.656 & 7.157 \\
\hline SD & 3.172 & 4.824 & 7.703 & 8.659 & 13.080 & 14.552 & 12.844 & 8.484 & 7.319 & 8.132 \\
\hline Min & 0.118 & 0.109 & 0.100 & 0.096 & 0.085 & 0.084 & 0.067 & 0.065 & 0.033 & Nil \\
\hline Max & 9.074 & 16.212 & 26.676 & 28.056 & 38.147 & 42.244 & 37.335 & 24.909 & 22.362 & 22.547 \\
\hline
\end{tabular}

Source: Computed.

Table.1.4 Variations in debt-equity ratio of all sample companies, 2005-06 to 2014-15

\begin{tabular}{|l|r|r|r|c|c|c|}
\hline \multicolumn{1}{|c|}{ Variation } & \multicolumn{1}{c|}{$\boldsymbol{S S}$} & $\boldsymbol{d} \boldsymbol{f}$ & \multicolumn{1}{c|}{$\boldsymbol{M S}$} & $\boldsymbol{F}$ & $\boldsymbol{P}$-value & $\boldsymbol{F}$ crit \\
\hline Between Groups & 52917.4 & 19 & 2785.13 & $\mathbf{7 . 5 1 7} * * *$ & $8.59 \mathrm{E}-15$ & 1.645 \\
\hline Within Groups & 66691.8 & 180 & 370.51 & & & \\
\hline Total & $\mathbf{1 1 9 6 0 9 . 2}$ & $\mathbf{1 9 9}$ & & & & \\
\hline
\end{tabular}

Note: $* * *$ indicates 1 per cent level of significance.

Source: Computed.

Table.1.5 Industry and year-wise mean net profit ratio, 2005-06 to 2014-15

\begin{tabular}{|l|r|r|r|r|r|r|r|r|r|r|r|}
\hline & 2006 & 2007 & 2008 & 2009 & 2010 & 2011 & 2012 & 2013 & 2014 & 2015 \\
\hline \multicolumn{10}{|c|}{ All Companies } \\
\hline Mean & 0.123 & 0.136 & 0.135 & 0.119 & 0.132 & 0.147 & 0.146 & 0.138 & 0.093 & 0.156 \\
\hline SD & 0.107 & 0.096 & 0.098 & 0.108 & 0.112 & 0.108 & 0.118 & 0.162 & 0.167 & 4.986 \\
\hline Min & -0.247 & -0.079 & 0.011 & -0.023 & -0.051 & -0.069 & -0.004 & -0.060 & -0.563 & -0.017 \\
\hline Max & 0.299 & 0.305 & 0.304 & 0.309 & 0.393 & 0.308 & 0.410 & 0.418 & 0.350 & 0.402 \\
\hline \multicolumn{10}{|c|}{ Information Technology } \\
\hline Mean & 0.209 & 0.208 & 0.210 & 0.183 & 0.226 & 0.231 & 0.221 & 0.216 & 0.143 & 0.254 \\
\hline SD & 0.060 & 0.057 & 0.085 & 0.096 & 0.092 & 0.067 & 0.112 & 0.124 & 0.264 & 0.113 \\
\hline Min & 0.077 & 0.119 & 0.024 & -0.023 & 0.074 & 0.085 & -0.004 & -0.012 & -0.563 & 0.049 \\
\hline Max & 0.299 & 0.305 & 0.304 & 0.309 & 0.393 & 0.308 & 0.410 & 0.418 & 0.350 & 0.402 \\
\hline \multicolumn{10}{|c|}{ Automobile } \\
\hline Mean & 0.038 & 0.064 & 0.059 & 0.055 & 0.038 & 0.063 & 0.071 & 0.060 & 0.044 & 0.057 \\
\hline SD & 0.105 & 0.058 & 0.040 & 0.040 & 0.050 & 0.059 & 0.048 & 0.063 & 0.066 & 0.055 \\
\hline Min & -0.247 & -0.079 & 0.011 & -0.003 & -0.051 & -0.069 & 0.001 & -0.060 & -0.098 & -0.017 \\
\hline Max & 0.143 & 0.116 & 0.130 & 0.127 & 0.124 & 0.132 & 0.154 & 0.168 & 0.138 & 0.164 \\
\hline
\end{tabular}


Table.1.6 Year-wise Return Differentials between the IT and Automobile Sectors

\begin{tabular}{|c|c|c|c|c|c|c|}
\hline \multirow{2}{*}{ Year } & \multicolumn{2}{|c|}{ IT } & \multicolumn{2}{c|}{ Automobile } & \multicolumn{2}{c|}{ Differential Return } \\
\cline { 2 - 7 } & Sensex & Nifty & Sensex & Nifty & Sensex & Nifty \\
\hline $2005-06$ & 0.128 & 0.111 & 0.143 & 0.124 & -0.015 & -0.013 \\
\hline $2006-07$ & 0.144 & 0.124 & 0.168 & 0.149 & -0.024 & -0.025 \\
\hline $2007-08$ & 0.142 & 0.162 & 0.163 & 0.185 & -0.021 & -0.023 \\
\hline $2008-09$ & -0.245 & -0.277 & -0.263 & -0.259 & 0.018 & -0.018 \\
\hline $2009-10$ & 0.259 & 0.246 & 0.234 & 0.246 & 0.025 & Nil \\
\hline $2010-11$ & 0.059 & 0.062 & 0.072 & 0.077 & -0.013 & -0.015 \\
\hline $2011-12$ & -0.107 & -0.108 & -0.107 & 0.026 & Nil & -0.134 \\
\hline $2012-13$ & 0.094 & 0.101 & 0.087 & 0.105 & 0.007 & -0.004 \\
\hline $2013-14$ & 0.037 & 0.029 & 0.054 & 0.048 & -0.017 & -0.019 \\
\hline $2014-15$ & 0.056 & 0.061 & 0.107 & 0.103 & -0.051 & -0.042 \\
\hline
\end{tabular}

Source: Computed.

Table.1.7 Regression Estimates: Factors influencing Market Returns of Companies: Information Technology

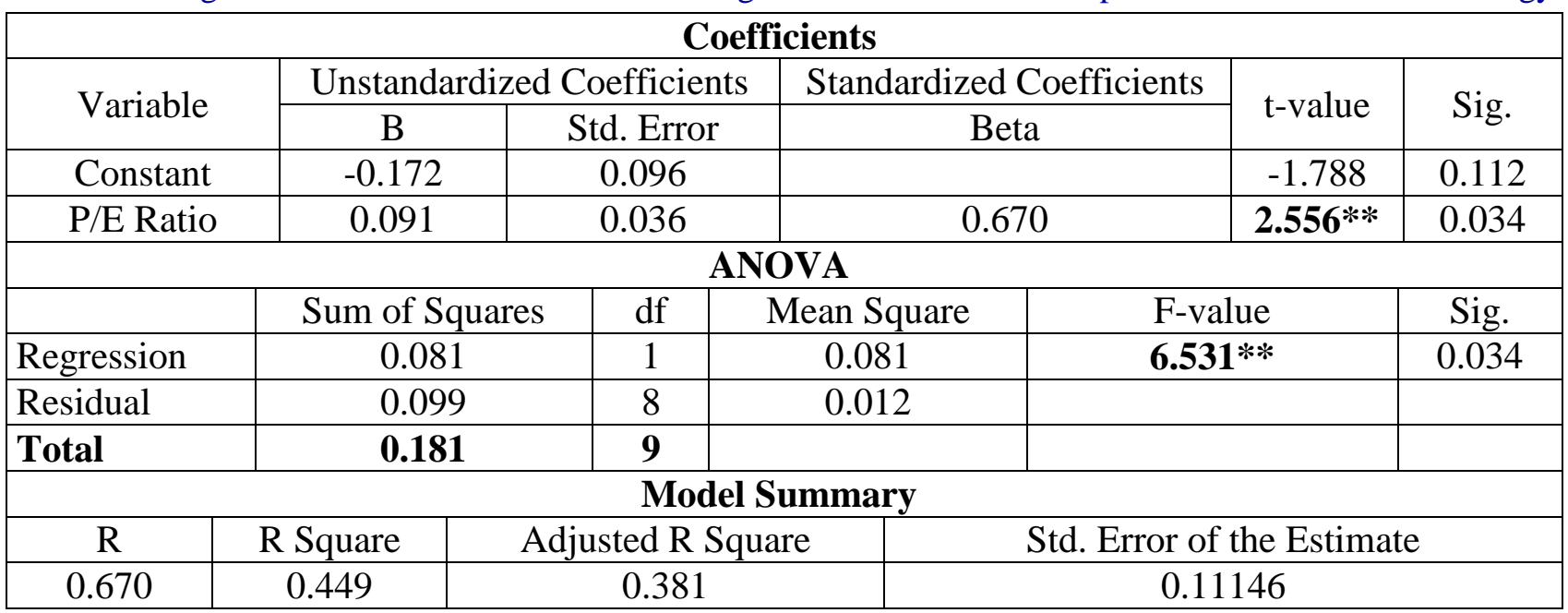

Note:** indicates significance at 5 per cent level.

Source: Computed.

Table.1.8 Regression Estimates: Factors influencing Market Returns of Companies: Automobile

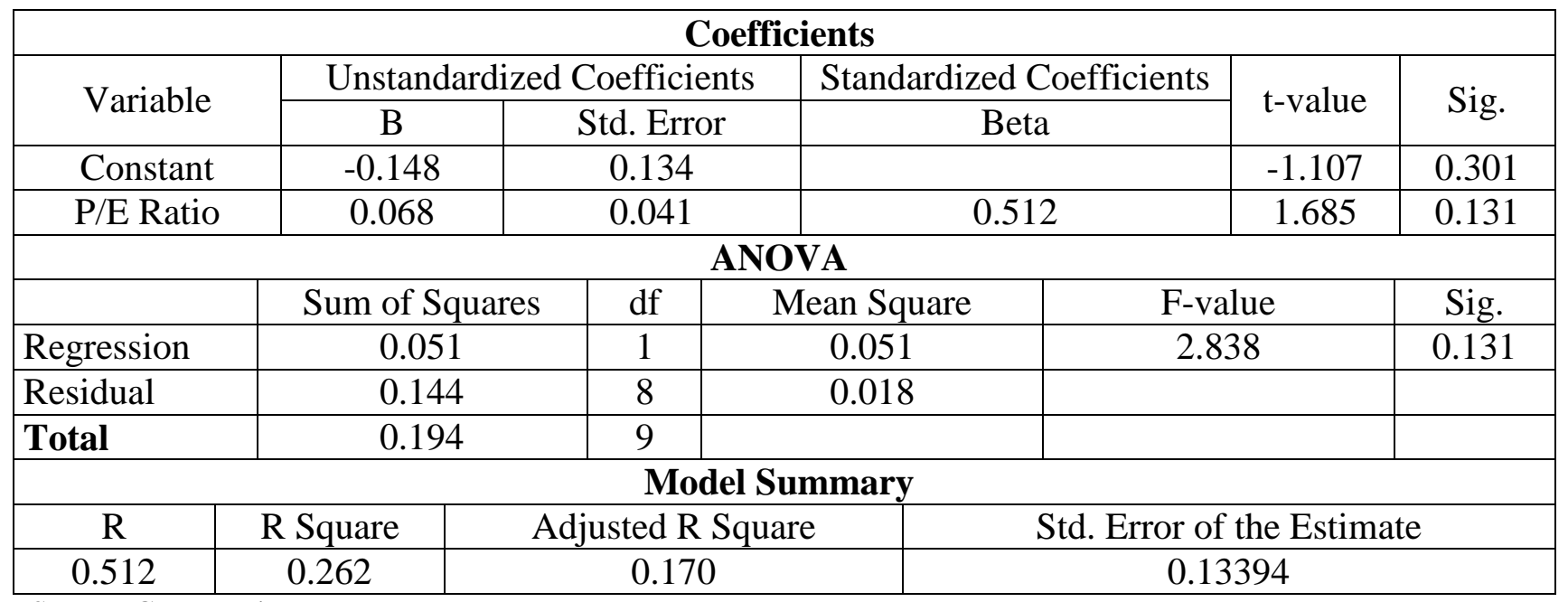

Source: Computed. 
In this background, this section makes an attempt to understand the relationship between financial performance of the two sectors and their market performance with the application of multi-variate regression model. For this purpose, the mean annual adjusted return earned by the IT and automobile sectors in terms of Sensex is taken as the dependent variable and the mean scores of each ratio of all ten companies under each sector are taken as the independent variables. The model is specified as given below:

$$
\begin{aligned}
\mathrm{RET}_{\text {it }} & =\alpha+\beta_{1} \mathrm{CR}_{\mathrm{it}}+\beta_{2} \mathrm{QR}_{\mathrm{it}}+\beta_{3} \mathrm{DER}_{\mathrm{it}}+\beta_{4} \mathrm{DAR}_{\mathrm{it}}+\beta_{5} \\
\mathrm{CF}_{\mathrm{it}} & +\beta_{6} \mathrm{NPR}_{\mathrm{it}} \\
& +\beta_{7} \mathrm{RoA}_{\mathrm{it}}+\beta_{8} \mathrm{RoE}_{\mathrm{it}}+\beta_{9} \mathrm{EPS}_{\mathrm{it}}+\beta_{10} \mathrm{ITR}_{\mathrm{it}}+\beta_{11} \\
\mathrm{ATR}_{\mathrm{it}} & +\beta_{12} \mathrm{PER}_{\mathrm{it}}+\mathrm{U}_{\mathrm{it}}(1)
\end{aligned}
$$

where, $\mathrm{RET}_{\mathrm{it}}$ is the adjusted mean return earned by the $\mathrm{i}^{\text {th }}$ company in time period $t$ under Sensex, $\beta_{1}$ to $\beta_{12}$ are the beta co-efficients of the respective financial ratios, $\alpha$ is the intercept term, while $U$ is the normal error term. This model has been estimated separately for the two sectors, but the results indicated that none of the financial ratios could significantly explain the changes in the market performance of the sector. However, there is a problem when all the 12 ratios are taken together, since the number of observations is only ten. Thus, in the next attempt only one ratio has been taken to represent each category, viz., current ratio from liquidity ratios, debtequity ratio from leverage ratios, net profit ratio from profitability ratios, inventory turnover ratio from efficiency ratios and price earnings ratio. Even this model failed to produce any satisfactory result for both sectors, since none of the ratios could significantly explain the dependent variable. Thus, ultimately each of the ratios has been run independently, which showed that only $\mathrm{P} / \mathrm{E}$ ratio could explain the changes in the dependent variable in a significant manner, only in the case of IT sector, while even that has not occurred in the case of automobile sector. The result for the IT sector is presented in table 7.

The table indicates that $\mathrm{P} / \mathrm{E}$ ratio is statistically significant at 5 per cent level and its beta value suggests that when there is one unit change in the P/E ratio, market performance of the IT sector goes up by 0.67 units and as the adjusted $\mathrm{R}^{2}$ value shows, the model explains only around 38 per cent of the changes in the dependent variable. The result for the automobile sector is presented in table 8 .
It is inferred from the table that in the automobile sector, not even $\mathrm{P} / \mathrm{E}$ ratio could significantly explain the changes in the market performance of the sector. This underscores the fact that performance of the companies in the stock market is quite dynamic and it is determined by so many factors, in which the financial performance of those companies is only one and the analysis implies that financial performance alone could not effectively capture the market performance of the sample companies during the study period.

\section{Conclusion}

This study examined the financial and the market performance of 20 sample companies taken from IT and automobile sectors for the period 2005-06 to 2014-15. This analysis brings out the fact that the liquidity and leverage ratios of the sample companies are quite less in both sectors and much less in the case of the automobile sector.

The poor equity position as against their asset position has made the companies to suffer in terms of their current ratio as well as debt-equity ratio. The brick and mortar sector has amassed huge debt, which has directly affected its leverage position in the study period. They are not able to boast off with their better profitability and efficiency ratios and they also suffer from huge degree of inconsistency in their performance over the period.

The selected IT and automobile companies could beat the market and also able to produce significant market adjusted returns over the years, in which the automobile companies have a clear upper hand, unlike in the case of financial performance. However, the degree of volatility is higher among both sectors than that of the market indices, which is a cause for concern for investors and traders, while it is especially higher in the IT sector than that of the automobile sector and thus, investing in the former calls for greater caution by the investors. Also, the financial performance of the companies alone cannot relied upon for investment in the market, particularly for short term gains, since many factors such as Government's policy regarding the economy in general, and the industry in particular, investments by the foreign institutional investors, level of competition, changes in the political situation also influence the extent of market return. 


\section{References}

Bhunia, Amalendu. 2010. Financial Performance of Indian Pharmaceutical Industry a Case Study, Asian J. Manage. Res., Vol. 29, pp. 8-13.

Chidambaram, K. and Muthukrishnan, S. 2002. Performance Appraisal- A Comparative Study of Madras Cements Limited and India Cements Limited, Indian J. Marketing, Vol.33, No.11, pp. 10-15.

Gupta, Prashant, Aman Shrivastav and Dinesh Sharma. 2011. Capital Structure and Financial Performance: Evidence from India, J. Accounting, Vol. 12, pp. 2633.

Kasseeah, Harshana. 2012. Financial Constraints and Leverage Decisions in Small and Medium-Sized Firms, J. Economics and Behavioural Studies, Vol. 4, No. 1, pp. 55-65

Kaur, Raghvir and Rao, N., Krishna. 2009. Determinants of Capital Structure, Experience of Indian Cotton
Textile Industry, Vilakshan: The XIMB J. Manage., Vol. 6, Issue 2, pp. 97-112.

Krishnaveni, M. 2008. Performance appraisal of an Indian Chemical Industry after Liberalization, Finance India, Vol. 22, No.3, pp. 571-580.

Kumar, Ghosh Santanu and Mondal Amitava. 2009. Intellectual Capital and Financial Performance, Evidence from the Indian Banking Industry, Proceedings of the European Conference on Intellectual Capital, pp. 217-227.

National Association of Software and Services Companies (NASSCOM). 2014. Economic Watch: Growth of India's IT Industry, Mumbai, pp 2-8. Accessed from www.ibef.org/industry/indiaautomobiles.aspx; on 17.01.2015.

Rajan, S., and Zingales. 1995. What do we know about Capital Structure? Some Evidence from International Data, J. Finance, Vol. 50, No. 5, pp. 1421-1460.

\section{How to cite this article:}

Geetha, E., 2017. Financial Performance Drives Market Performance-An Empirical Investigation by Comparing Two Industries in India. Int.J.Curr.Res.Aca.Rev. 5(6), 101-107. doi: https://doi.org/10.20546/ijcrar.2017.506.014 